\title{
Aerobic fitness, energy balance, and body mass index are associated with training load assessed by activity energy expenditure
}

Citation for published version (APA):

Tanskanen, M., Uusitalo, A. L., Hakkinen, K., Nissila, J., Santtila, M., Westerterp, K. R., \& Kyrolainen, H. (2009). Aerobic fitness, energy balance, and body mass index are associated with training load assessed by activity energy expenditure. Scandinavian Journal of Medicine \& Science in Sports, 19, 871-878. https://doi.org/10.1111/j.1600-0838.2008.00857.x

Document status and date:

Published: 01/01/2009

DOI:

10.1111/j.1600-0838.2008.00857.x

Document Version:

Publisher's PDF, also known as Version of record

Document license:

Taverne

Please check the document version of this publication:

- A submitted manuscript is the version of the article upon submission and before peer-review. There can be important differences between the submitted version and the official published version of record.

People interested in the research are advised to contact the author for the final version of the publication, or visit the DOI to the publisher's website.

- The final author version and the galley proof are versions of the publication after peer review.

- The final published version features the final layout of the paper including the volume, issue and page numbers.

Link to publication

\footnotetext{
General rights rights.

- You may freely distribute the URL identifying the publication in the public portal. please follow below link for the End User Agreement:

www.umlib.nl/taverne-license

Take down policy

If you believe that this document breaches copyright please contact us at:

repository@maastrichtuniversity.nl

providing details and we will investigate your claim.
}

Copyright and moral rights for the publications made accessible in the public portal are retained by the authors and/or other copyright owners and it is a condition of accessing publications that users recognise and abide by the legal requirements associated with these

- Users may download and print one copy of any publication from the public portal for the purpose of private study or research.

- You may not further distribute the material or use it for any profit-making activity or commercial gain

If the publication is distributed under the terms of Article $25 \mathrm{fa}$ of the Dutch Copyright Act, indicated by the "Taverne" license above, 


\title{
Aerobic fitness, energy balance, and body mass index are associated with training load assessed by activity energy expenditure
}

\author{
M. Tanskanen ${ }^{1}$, A. L. T. Uusitalo ${ }^{2}$, K. Häkkinen ${ }^{1}$, J. Nissilä ${ }^{3}$, M. Santtila ${ }^{4}$, K. R. Westerterp ${ }^{5}$, H. Kyröläinen ${ }^{1}$ \\ ${ }^{1}$ Department of Biology of Physical Activity, University of Jyväskylä, Jyväskylä, Finland, ${ }^{2}$ Department of Clinical Physiology and \\ Nuclear Medicine, Helsinki University Hospital, Helsinki, Finland, ${ }^{3}$ Polar Electro Oy, Kempele, Finland, ${ }^{4}$ Personnel Division of \\ the Defence Staff, Finnish Defence Forces, Helsinki, Finland, ${ }^{5}$ Department of Human Biology, Maastricht University, Maastricht, \\ The Netherlands \\ Corresponding author: Minna Tanskanen, Department of Biology of Physical Activity, University of Jyväskylä, Kidekuja 2, \\ Snowpolis, FI-88610 Vuokatti, Finland. Tel: +35886178643, Fax:+35886178641, E-mail: minna.tanskanen@sport.jyu.fi
}

Accepted for publication 26 June 2008

\begin{abstract}
The present study examined whether activity energy expenditure related to body mass $(\mathrm{AEE} / \mathrm{kg})$ is associated with maximal aerobic fitness $\left(\mathrm{VO}_{2 \mathrm{max}}\right)$, energy balance, and body mass index (BMI) during the 2 hardest weeks of the military basic training season (BT). An additional purpose was to study the accuracy of the pre-filled food diary energy intake. Energy expenditure (EE) with doubly labeled water, energy intake (EI), energy balance, and mis-recording was measured from 24 male conscripts with varying $\mathrm{VO}_{2 \max }$. $\mathrm{AEE} / \mathrm{kg}$ was calculated as $(\mathrm{EE} \times 0.9$ - measured basal metabolic rate)/body mass. The reported EI was lower $(P<0.001)$ than EE $(15.48 \mathrm{MJ} /$ day $)$ and mis-recording of
\end{abstract}

the pre-filled diary was $-\mathbf{2 0 \%}$. The negative energy balance $(-6 \pm 26 \%)$ was non-significant; however, the variation was high. The subjects with a low $\mathrm{VO}_{2 \max }$, a high BMI, and a negative energy balance were vulnerable to low AEE/kg. However, in the multivariate regression analysis only BMI remained in the model, explaining $33 \%$ of the variation in AEE $/ \mathrm{kg}$. During wintertime BT, AEE $/ \mathrm{kg}$ is affected by energy balance, $\mathrm{VO}_{2 \max }$, and $\mathrm{BMI}$. From these three factors, overweight limits high-level training the most. Furthermore, an optimal energy balance facilitates physical performance and enables high training loads to be sustained during the BT season.
To improve the physical fitness of new conscripts in the Finnish Defense Forces, the amount of physical training during a basic military training period (BT) was doubled in 1998 (Training Division of the Defence Staff, 2003). In contrast, the fitness level of young men entering the Finnish compulsory military service has declined, with a concomitant increase in body mass during the last 25 years (Santtila et al., 2006). It is not known whether the overall training load during military service is suitable for the current conscripts, who exhibit varying physical fitness levels.

Aerobic fitness, as measured by maximal oxygen uptake $\left(\mathrm{VO}_{2 \max }\right)$, is an important component of the physical fitness profile [American College of Sports Medicine (ACSM), 2001]. In addition, aerobic fitness has been found to be an important component of performance, and can thus influence the ability to sustain the training load during BT (Jones \& Knapik, 1999), while low aerobic fitness increases the risk of injury and illness, leading to limited duty days during BT (Jones \& Knapik, 1999; Knapik et al., 2001). However, the measurement of training load and performance over a long period of BT, when training includes different kind of activities, is challenging. A measure of physical activity level known as PAL, an average daily multiple of basal metabolic rate (BMR), is used to classify occupational workload and leisure-time physical activity according to the following criteria: sedentary $(1.4 \times \mathrm{BMR})$, normal $(1.8 \times \mathrm{BMR})$, or active $(2.0 \times \mathrm{BMR})$ (Nordic Nutrition Recommendations, 2004). Another way to describe physical activity is the energy cost of activity (AEE) with corrections for differences in body size (Ekelund et al., 2004). AEE includes muscular activity, including shivering and fidgeting as well as purposeful physical exercise (Poehlman, 1989), and it is affected by the intensity and duration of activity as well as by individual differences in movement efficiency (Ainsworth et al., 1993).

All conscripts train together according to the same program throughout BT. Thus, the physical activity is not optional and the PAL should be the same regardless of the subject's fitness status. From another perspective, individuals with low aerobic fitness will experience greater physiological stress 


\section{Tanskanen et al.}

relative to their maximum capacity at any given absolute level of aerobic work (Jones \& Knapik, 1999). Thus, it could be hypothesized that the less fit conscripts will experience more physiological stress during physical activity because they have to work at higher relative intensities, and aerobic fitness is not necessarily related to AEE.

The doubly labeled water (DLW) method has been used as a gold standard for the measurement of total daily energy expenditure (EE) (Schoeller et al., 1986; Westerterp et al., 1995b). Several studies have used the DLW method in military operations, for example during rigorous field training exercise (DeLany et al., 1989; Forbes-Ewan et al., 1989; Mudambo et al., 1997; Castellani et al., 2006), in extremely cold environments (Hoyt et al., 1991; Jones et al., 1993), or in the garrison (Mudambo et al., 1997). In combination with the measurement of BMR, the DLW method allows the calculation of AEE and PAL over prolonged periods in military environments.

Energy intake (EI) has been found to influence EE and activity level (DeLany et al., 1989; Klein \& Goran, 1993; Thompson et al., 1995). In addition, unfamiliar stressful situations have been found to affect EI (Popper et al., 1989). Most young men entering the military service will have their first experience of demanding physical training, eating outdoors, and performing overnight exercises in a forest. The common way to assess EI is a selfreported food diary. However, when DLW has been used to validate EI, a discrepancy between self-reported EI and measured EE has been observed, mainly due to under-reporting (Goris \& Westerterp, 1999). Under-reporting can be divided into misrecording and under-eating; mis-recording refers to a discrepancy between EI and measured EE with no change in body mass, and under-eating is a discrepancy accompanied by a decline in body mass over the food-recording interval (Goris \& Westerterp, 1999), representing a negative energy balance. With a description of mis-recording, an estimate of true EI could be obtained.

No studies have examined the associations between soldiers' maximal aerobic fitness, energy balance, body size, and activity during the BT season in winter conditions. Thus, the purpose of this study was to determine the importance of $\mathrm{VO}_{2 \max }$, energy balance, and body size on AEE related to body mass $(\mathrm{AEE} / \mathrm{kg})$ during the 2 hardest weeks of the wintertime BT season. In the present study, the activity level (AEE/ $\mathrm{kg}$ ) equated to the training load during the entire period of BT. An additional purpose was to study the accuracy of a self-reported pre-filled food diary in the military environment without food weighing, but with known food composition.

\section{Methods}

\section{Subjects}

Voluntary male conscripts $(n=24)$ from the Signal Battalion of Northern Finland with varying $\mathrm{VO}_{2 \max }$ levels participated in the present 2-week study. Conscript is a definition of a person who enters compulsory military service, which is strictly performed according to the standard direction of the Defense Command. The subjects were selected from a total of 131 subjects, who volunteered for the present study. From the original subjects, 47 were discarded based on cardiorespiratory or musculo-skeletal disorders, and incomplete fulfilment or willingness to perform special duties. The remaining 84 were divided into three categories according to their level of voluntary physical activity before military service. From each category, 20 subjects were selected, yielding a total of 60 randomly ordered subjects. Finally, these 60 subjects were divided into three groups of equal numbers according to their initial $\mathrm{VO}_{2 \max }(\mathrm{mL} / \mathrm{kg} / \mathrm{min})$ when entering military service: $>45 \mathrm{~mL} / \mathrm{kg} / \mathrm{min}$ for group $1 ; 40-44.9 \mathrm{~mL} / \mathrm{kg} / \mathrm{min}$ for group 2; and $<39.9 \mathrm{~mL} / \mathrm{kg} / \mathrm{min}$ for group 3. From each group, eight subjects were randomly selected, yielding a total of 24 subjects. Subject characteristics are presented in Table 1. The subjects' physical fitness characteristics were representative of young Finnish men (Santtila et al., 2006). All subjects were fully informed of the experimental protocol and gave their written consent to participate in the study. They were also advised of their right to withdraw from the investigation at any time. The study protocol was approved by the Finnish Defence Forces and the Ethics Committees of the University of Jyväskylä and the Kainuu region, respectively.

\section{Study protocol}

The study took place during wintertime in Finland, when daily outdoor temperatures ranged between $-6{ }^{\circ} \mathrm{C}$ and $-19{ }^{\circ} \mathrm{C}$, with an average of $-11^{\circ} \mathrm{C}$ (according to the local weather station). The experimental protocol is presented in Table 2 . The overall physical load of the 8-week BT season was set according to the standard direction of the Defense Command. The study took place during the last 2 weeks of BT, which was the most strenuous period of the BT season. Food and water intake were ad libitum during the study. The average sleeping time at the garrison was from 10 p.m. to 5:45 a.m. Military education included physically demanding activities such as marching, combat training, and sport-related physical training. The conscripts also carried combat gear weighing $25 \mathrm{~kg}$, including clothing, particularly during marching and combat training. In addition, the training included an overnight field exercise. Garrison training involved theoretical education in classroom settings, material handling, shooting, and general military education, such as close-order drills. Table 2 provides

Table 1. Physical characteristics of the subjects $(N=24)$

\begin{tabular}{lcc}
\hline & Mean $\pm \mathrm{SD}$ & Range \\
\hline Age (years) & $19.6 \pm 0.2$ & $19.1-20.1$ \\
Height $(\mathrm{cm})$ & $171 \pm 7.0$ & $155-178$ \\
Body mass $(\mathrm{kg})$ & $77.6 \pm 14.9$ & $56.3-111.3$ \\
Body mass index $\left(\mathrm{kg} / \mathrm{m}^{2}\right)$ & $24.3 \pm 3.8$ & $18.3-32.2$ \\
Fat-free mass $(\mathrm{kg})$ & $59.7 \pm 9.4$ & $42.4-72.4$ \\
Fat mass $(\mathrm{kg})$ & $18.0 \pm 9.7$ & $5.5-44.0$ \\
Fat $(\%)$ & $22.1 \pm 7.9$ & $9.4-39.5$ \\
$\mathrm{VO}_{2 \max }(\mathrm{L} / \mathrm{min})$ & $3.6 \pm 0.6$ & $2.4-4.5$ \\
$\mathrm{VO}_{2 \max }(\mathrm{mL} / \mathrm{kg} / \mathrm{min})$ & $47 \pm 7$ & $30-58$ \\
\hline
\end{tabular}

$\mathrm{VO}_{2 \max }$ refers to maximal oxygen uptake. 
AEE, $\mathrm{VO}_{2 \max }$, energy balance, and BMI

Table 2. The experimental protocol

\begin{tabular}{|c|c|c|c|c|c|c|c|c|c|c|c|c|c|c|c|c|c|}
\hline & \multirow{2}{*}{$\begin{array}{l}\text { Days before } \\
\text { DLW }\end{array}$} & \multicolumn{16}{|c|}{ Days during the DLW assessment period } \\
\hline & & 0 & 1 & 2 & 3 & 4 & 5 & 6 & 7 & 8 & 9 & 10 & 11 & 12 & 13 & 14 & 15 \\
\hline $\begin{array}{l}\text { BMR measure } \\
\mathrm{VO}_{2 \max } \text { test } \\
\text { DLW dose }\end{array}$ & $\begin{array}{l}-28 \ldots-1 \\
-9 \ldots-5\end{array}$ & $x$ & & & & & & & & & & & & & & & \\
\hline Urine sample & & $x$ & $x$ & & & & & & & $x$ & & & & & & & $x$ \\
\hline Body composition & & $x$ & $x$ & & & & & & & $x$ & & & & & & & $x$ \\
\hline Dietary record & & & & $x$ & $x$ & $x$ & & & $x$ & $x$ & & & $x$ & & & $x$ & $x$ \\
\hline Overnight field exercise & & & & $x$ & $x$ & $x$ & $x$ & & & & & & & & & & \\
\hline Skiing march & & & & & & & & & $x$ & & & & & & & & \\
\hline Shooting exercise & & & & & & & & & & $x$ & & & & & & & \\
\hline Combat shooting exercise & & $x$ & $x$ & & & & & & & & & & & & & & \\
\hline Combat training & & & & & & & & & & & & & & & & & $x$ \\
\hline March test & & & & & & & & & & & $x$ & & & & & & \\
\hline Weekend leave & & & & & & & & & & & & $\mathrm{x}$ & $x$ & & & & \\
\hline
\end{tabular}

BMR, basic metabolic rate; DLW, doubly labeled water.

a more detailed description of the other activities performed out of garrison.

$\mathrm{VO}_{2 \max }$

To determine $\mathrm{VO}_{2 \max }$, the conscripts performed a maximal treadmill test. The start of the test involved walking for $3 \mathrm{~min}$ at $4.6 \mathrm{~km} / \mathrm{h}$ and walking/jogging at $6.3 \mathrm{~km} / \mathrm{h}$ (1\% slope) as a warm-up. Thereafter, exercise intensity was increased every $3 \mathrm{~min}$ to induce an increase of $6 \mathrm{~mL} / \mathrm{kg} / \mathrm{min}$ in the theoretical $\mathrm{VO}_{2 \max }$ demand of running (ACSM, 2001). This was achieved by increasing the initial running speed of $4.6 \mathrm{~km} / \mathrm{h}$ by a mean of $1.2 \mathrm{~km} / \mathrm{h}$ (range $0.6-1.4 \mathrm{~km} / \mathrm{h}$ ), and by increasing the initial grade of $1^{\circ}$ by a mean grade of $0.5^{\circ}$ (range $0.0-1.0^{\circ}$ ) up to the point of exhaustion (ACSM, 2001). Pulmonary ventilation and respiratory gas exchange data were measured on-line using the breath-by-breath method (Jaeger Oxygen Pro; Viasys Healthcare GmbH, Hoechberg, Germany), and mean values were calculated at 1-min intervals for statistical analysis. Heart rate was continuously recorded at 5-s intervals using a telemetric system (Polar810i; Polar Electro Oy, Kempele, Finland). Blood lactate was determined 1 min after completion of the exercise from a fingertip blood sample using a lactate analyzer (LactatePro ${ }^{B}$, Arkray, Japan). The criteria used for determining $\mathrm{VO}_{2 \max }$ were: $\mathrm{VO}_{2 \max }$ and heart rate did not increase despite an increase in the grade and/or the speed of the treadmill, a respiratory exchange ratio (RER) higher than 1.1 , and a post-exercise blood lactate higher than $8 \mathrm{mmol} / \mathrm{L}$ (ACSM, 2001). All participants satisfied these criteria.

\section{Anthropometry and body composition}

Body mass was measured with an accuracy of $0.01 \mathrm{~kg}$ (Inbody720 body composition analyzer; Biospace Co. Ltd., Seoul, Korea $)$ at the beginning $\left(\mathrm{BM}_{\text {pre }}\right)$, after 1 week $\left(\mathrm{BM}_{\mathrm{mid}}\right)$, and at the end of the experimental period $\left(\mathrm{BM}_{\text {post }}\right)$. The measurements were performed between 6:00 and 7:00 a.m. after an overnight fast and after voiding, with no exercise for $12 \mathrm{~h}$ before the test. The physical activities in the daily program were planned to be light on the day preceding each measurement, and fluid status was estimated to be in balance based on the dietary records of the subjects. The subjects were barefoot and they wore $\mathrm{T}$-shirts and trousers. The $\mathrm{BM}_{\text {mean }}$ was presented as an individual average of $\mathrm{BM}_{\text {pre }}, \mathrm{BM}_{\text {mid }}$, and $\mathrm{BM}_{\text {post }}$, and the change in $\mathrm{BM}(\Delta \mathrm{BM})$ was calculated as the difference between $\mathrm{BM}_{\text {post }}$ and $\mathrm{BM}_{\text {pre }}$. Body height was measured to the nearest $0.5 \mathrm{~cm}$ using a wall-mounted stadiometer. Body mass index (BMI) was calculated as $\mathrm{BM}_{\text {pre }}$ divided by the body height squared. Fat-free mass (FFM) was calculated from total body water (TBW) as follows: $\mathrm{FFM}=\mathrm{TBW} / 0.732$ (Pace \& Rathburn, 1945). Fat mass (FM) was calculated as $\mathrm{BM}_{\text {pre }}-\mathrm{FFM}$, and percentage of body fat as $\mathrm{FM} / \mathrm{BM}_{\text {pre }} \times 100$. TBW was measured with deuterium dilution according to the Maastricht protocol (Westerterp et al., 1995b). TBW was calculated as the ${ }^{2} \mathrm{H}$ dilution space divided by 1.04 , correcting for exchange of the ${ }^{2} \mathrm{H}$ label with non-aqueous $\mathrm{H}$ of body solids (Schoeller et al., 1980).

\section{BMR}

The BMR was measured once, for practical reasons, $\sim 19$ days before the DLW period. After an 11-h fast, the subject woke up at 5:30 a.m. for BMR measurements performed in a semi-recumbent position, lying for $30 \mathrm{~min}$ in a quiet room. Oxygen consumption and carbon dioxide measurements were made with the same gas analyzer (Jaeger Oxygen Pro) as that used in the $\mathrm{VO}_{2 \max }$ test. BMR was automatically calculated from the oxygen and carbon dioxide values as follows: $\mathrm{EE}=1.59 \times \mathrm{VCO}_{2}+5.68 \times \mathrm{VO}_{2}-2.17 \times$ urinary nitrogen (Weir, 1949), where urinary nitrogen was assumed to be $15 \mathrm{~g}$ /day. In the analysis, BMR was determined during the last $15 \mathrm{~min}$ of the 30 -min measurement period.

\section{EE, AEE, AEE/kg, and PAL}

EE was measured with DLW according to the Maastricht Protocol. (Westerterp et al., 1995b). Briefly, at 10:00 p.m., before the measurements and after collecting a baseline urine sample, the subjects drank a weighed mixture of ${ }^{2} \mathrm{H}_{2} \mathrm{O}$ (99.9 at \%) and $\mathrm{H}_{2}^{18} \mathrm{O}(10 \mathrm{at} \%)$, resulting in an initial excess TBW enrichment of 150 p.p.m. for deuterium and 300 p.p.m. for oxygen-18. TBW was estimated from calculated body composition, based on height, weight, age, and gender, using the equation of Deurenberg et al. (1991), assuming a $73 \%$ hydration of FFM. Subjects consumed no foods or fluids for $10 \mathrm{~h}$ after dose administration, during the overnight equilibration of the isotopes with the body water. Subsequent urine samples were collected from the second and the third voiding on the morning of day 1 , and from the first and the second voiding on the morning of days 8 and 15. Isotope quantities 


\section{Tanskanen et al.}

(deuterium and oxygen-18) in the urine were measured using an isotope ratio mass spectrometer (Optima, VG Isogas, Middlewich, UK), and $\mathrm{CO}_{2}$ production was calculated from isotope ratios at the baseline, and days 1,8 , and 15 , using the equations of Schoeller et al. (1986). $\mathrm{CO}_{2}$ production was converted to daily metabolic rate using an energy equivalent based on the individual macronutrient composition of the diet (Black et al., 1986). AEE was calculated as EE $\times 0.9-$ BMR, assuming diet-induced thermogenesis of $10 \%$ (Poehlman, 1989). To remove the confounding effect of body size (Ekelund et al., 2004), AEE was adjusted for $\mathrm{BM}_{\text {mean }}(\mathrm{AEE} / \mathrm{kg})$. PAL was calculated as EE/BMR.

\section{El}

For studying EI, the subjects kept a pre-filled food diary for 3-4 days in two phases. Altogether, habitual food intake was obtained from 7 days during the study. The pre-filled food diary included information about the food served in the military. Details of the food and fluids that were served, including their composition, were known beforehand, and this information was written in the pre-filled diary. Thus, the subjects were only required to record the amount of food and fluid that they consumed. The subjects had completed these diaries twice before the study to ensure that they were familiar with reporting food intake. The subjects received detailed verbal and written instructions about common household measures, such as cups and tablespoons, and specific information about the quantity of the measurements. They were asked to record brand names of every non-military food that they consumed, as well as their cooking methods. In addition, they were advised to be as accurate as possible in recording the amount and type of food and fluid consumed. Any questions, ambiguities, or omissions were resolved individually and controlled via personal interviews, which included questions about whether they ate less during the recording period (under-eating) or wrote down everything they consumed (mis-recording). Daily nutritional consumption was quantified by the computer program Nutrica ${ }^{B}$ software (version 3.11, Finland). The recipes of the food that was consumed in military conditions were added to the database.

\section{Accuracy of the food diary and estimated true El}

Estimated true EI (TrueEI) was calculated using EI and changes in body energy stores $(\Delta \mathrm{ES})$, which was calculated from changes in body mass, assuming that a body mass of $1 \mathrm{~kg}$ is equivalent to $30 \mathrm{MJ}(75 \% \mathrm{FM}, 25 \% \mathrm{FFM}$, with $73 \%$ water; Westerterp et al., 1995a). Under-reporting, mis-recording, under-eating (energy balance), and TrueEI were calculated as follows:

$$
\begin{aligned}
& \text { Under-reporting }(\%)=(\mathrm{EI}-\mathrm{EE}) / \mathrm{EE} \times 100 \\
& \begin{aligned}
\text { Mis-recording }(\%) & =[(\mathrm{EI}-\Delta \mathrm{ES})-\mathrm{EE}] / \mathrm{EE} \times 100 \\
\text { Under-eating }(\%) & =\text { energy balance }(\%) \\
& =[(\Delta \mathrm{ES} / \text { study days }) / \mathrm{EE}] \times 100
\end{aligned}
\end{aligned}
$$

TrueEI $=\mathrm{EI}-$ mis-recording $=\mathrm{EI}-[(\mathrm{EI}-\Delta \mathrm{ES})-\mathrm{EE}]$

$$
=\Delta \mathrm{ES}+\mathrm{EE}
$$

\section{Statistical analysis}

Changes in BM were tested by a paired samples $t$-test. FM was $\log$ transformed to reduce skewness. To remove the potential effect of body size on $\mathrm{VO}_{2 \max }$, FFM-adjusted values for
$\mathrm{VO}_{2 \max }\left(\mathrm{VO}_{2 \operatorname{maxFFM}}\right)$ were calculated according to the method described by Toth et al. (1993). Pearson correlation coefficients were computed to determine the linear relationship between EE, AEE, AEE $/ \mathrm{kg}$, PAL, BMR, and $\mathrm{VO}_{2 \max F F M}$ (L/min), energy balance, and body composition (BMpre, FM, FFM, and BMI). To examine the effects of BMI, fitness, and under-eating on $\mathrm{AEE} / \mathrm{kg}$, the subjects were divided into tertiles with equal numbers of subjects according to their BMI $\left(<22.5 \mathrm{~kg} / \mathrm{m}^{2}\right.$ for LowBMI; $22.6-24.8 \mathrm{~kg} / \mathrm{m}^{2}$ for ModerateBMI; and $>24.9 \mathrm{~kg} / \mathrm{m}^{2}$ for HighBMI), $\mathrm{VO}_{2 \operatorname{maxFFM}}$ $\left(<3.44 \mathrm{~L} / \mathrm{min}^{2}\right.$ for LowFIT; $3.45-3.68 \mathrm{~L} / \mathrm{min}^{2}$ for ModerateFIT; and $>3.69 \mathrm{~L} / \mathrm{min}^{2}$ for FIT), and energy balance ( $>0.76 \mathrm{MJ} /$ day for Low; $-2.16-0.75 \mathrm{MJ} /$ day for Moderate; and $<-2.17 \mathrm{MJ} /$ day for High under-eating). One-way ANOVA with the LSD post hoc test was used to compare the differences in $\mathrm{AEE} / \mathrm{kg}$, energy balance, and fitness or BMI between the category groups. For further evaluation of the interaction and to identify the predictors of $\mathrm{AEE} / \mathrm{kg}$ from the independent variables, multivariable linear regression analysis was used. The independent variables were $\mathrm{VO}_{2 \operatorname{maxFFM}}$ $(\mathrm{L} / \mathrm{min})$, body composition, and energy balance. The final model was computed after the multicollinearity diagnostic and the assumptions for regression analysis were fulfilled. All statistical analyses were performed using SPSS (14.0.1. 2005; SPSS Inc., Chicago, Illinois, USA). The level of statistical significance was set at $P<0.05$.

\section{Results}

BMR $(7.66 \pm 0.92 \mathrm{MJ} /$ day $)$ represented $50 \pm 5 \%$ and AEE $(6.26 \pm 1.21 \mathrm{MJ} /$ day $) 40 \pm 5 \%$ of the total EE (Table 3). The reported EI of $11.5 \pm 3.2 \mathrm{MJ} /$ day was significantly lower than the measured EE (15.5 \pm $1.6 \mathrm{MJ} /$ day), and thus the results revealed significant under-reporting $(-26.0 \pm 17.5 \%, P<0.001)$. The data of reported intake indicated that daily carbohydrate consumption in relation to the total reported EI was $58 \pm 4 \%(5.2 \pm 1.6 \mathrm{~g} / \mathrm{kg})$, fat $27 \pm 4 \%(1.1 \pm$ $0.4 \mathrm{~g} / \mathrm{kg})$, protein $14 \pm 2 \%(1.3 \pm 0.4 \mathrm{~g} / \mathrm{kg})$, and alcohol $0.3 \pm 0.9 \% \quad(0.01 \pm 0.04 \mathrm{~g} / \mathrm{kg})$. When the reported EI was corrected for the mis-recording

Table 3. Energy expenditure (EE), its components, and energy intake (EI) variables in 24 conscripts

\begin{tabular}{lcc}
\hline & Mean \pm SD & \multicolumn{1}{l}{ Range } \\
\hline EE (MJ/day) & $15.48 \pm 1.65$ & $12.75-18.51$ \\
AEE (MJ/day) & $6.26 \pm 1.21$ & $4.18-8.94$ \\
AEE/kg (MJ/day/kg) & $0.08 \pm 0.02$ & $0.04-0.13$ \\
$\mathrm{PAL}^{*}$ & $2.03 \pm 0.21$ & $1.68-2.47$ \\
$\mathrm{BMR}(\mathrm{MJ} /$ day) & $7.66 \pm 0.92$ & $5.50-9.44$ \\
El (MJ/day) & $11.52 \pm 3.23^{\star \star \star}$ & $6.73-17.77$ \\
Estimated true El (MJ/day) & $14.62 \pm 4.17$ & $4.90-22.35$ \\
Underreporting (\%) & $-26.0 \pm 17.5$ & $-52.4-5.6$ \\
Under-eating = energy & $-5.6 \pm 25.5$ & $-66.3-41.7$ \\
balance (\%) & & \\
Mis-recording (\%) & $-20.4 \pm 26.3$ & $-82.9-29.5$ \\
\hline
\end{tabular}

${ }^{\star}$ Calculated as EE/BMR.

${ }^{\star * *}$ Difference with $\mathrm{EE}(P<0.001)$.

$\mathrm{AEE}$, activity energy expenditure; $\mathrm{AEE} / \mathrm{kg}$, activity energy expenditure related to body mass; PAL, physical activity level; BMR, basal metabolic rate. 


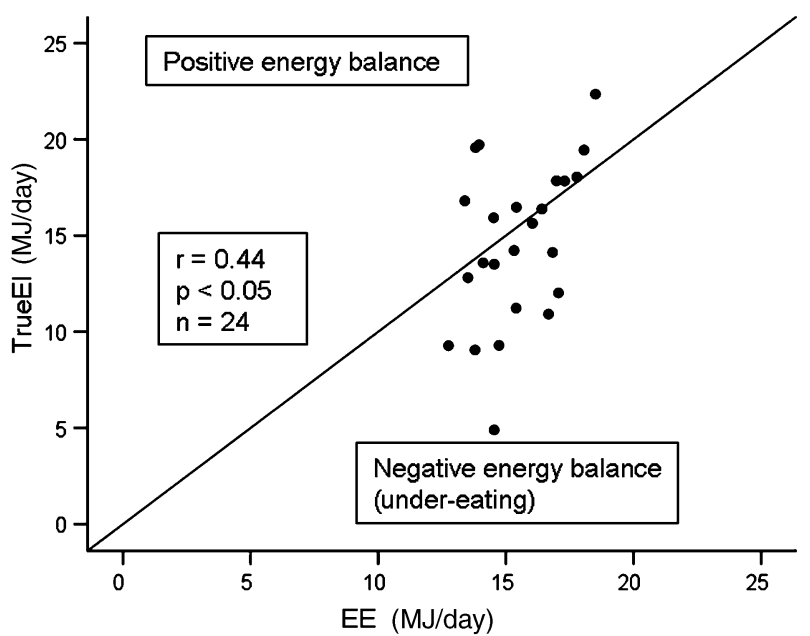

Fig. 1. Relationship between estimated true energy intake (TrueEI) and energy expenditure (EE). The line represents the energy balance.

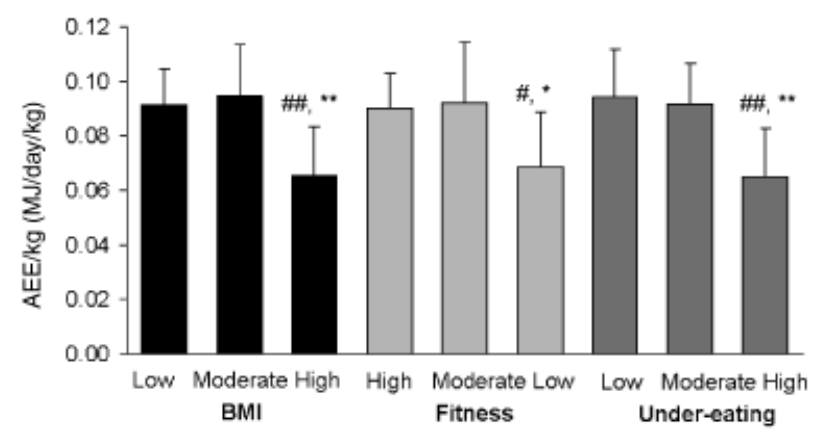

Fig. 2. AEE $/ \mathrm{kg}$ in Low, Moderate, and High BMI (a), fitness (b), and under-eating (c) groups. Significant difference as compared with: Low BMI and under-eating ${ }^{\# \#} P<0.01$, Moderate BMI and under-eating $* * P<0.01$, High fitness ${ }^{\#} P<0.05$, Moderate fitness $* P<0.05$. BMI, body mass index; AEE, activity energy expenditure.

$(-20.4 \pm 26.3 \%)$, TrueEI did not differ from EE $(-5.6 \pm 25.5 \%$, NS), which indicates a non-significant negative energy balance (under-eating) of the present subjects. However, Fig. 1 indicates that few subjects had a negative energy balance, which was negatively related to $\mathrm{BM}_{\text {pre }}(r=-0.73, P<0.001)$, FM $(r=-0.83, P<0.001)$, and BMI $(r=-0.80$, $P<0.001)$.

The subjects in the HighBMI group had lower AEE $/ \mathrm{kg}(P<0.01)$ compared with the subjects in the LowBMI and ModerateBMI groups (Fig. 2a). The HighBMI subjects also had a significantly higher negative energy balance $(-4.2 \pm 3.08 \mathrm{MJ} /$ day $)$ compared with those subjects in the LowBMI (1.6 \pm $3.23 \mathrm{MJ} /$ day, $P<0.001)$ and the ModerateBMI $(0.11 \pm 2.30 \mathrm{MJ} /$ day, $P<0.01)$ groups. The LowBMI and ModerateBMI groups did not differ according to $\mathrm{AEE} / \mathrm{kg}$, and both energy balance and $\mathrm{VO}_{2 \operatorname{maxFFM}}$ did not differ between the three BMI groups either.
$\mathrm{AEE} / \mathrm{kg}$ was also lower in LowFIT compared with ModerateFIT and FIT $(P<0.05)$ (Fig. 2b), but BMI and energy balance did not differ between these three fitness groups. Furthermore, AEE $/ \mathrm{kg}$ was lower among subjects in the High under-eating group compared with the Low and Moderate under-eating groups $(P<0.01)$ (Fig. $2 \mathrm{c})$. These subjects also had higher BMI $\left(27.8 \pm 3.6 \mathrm{~kg} / \mathrm{m}^{2}\right)$ compared with subjects in the Low $\left(21.4 \pm 2.4 \mathrm{~kg} / \mathrm{m}^{2}, P<0.001\right)$ and Moderate $\left(23.6 \pm 1.9 \mathrm{~kg} / \mathrm{m}^{2}, P<0.01\right)$ under-eating groups and lower $\mathrm{VO}_{2 \operatorname{maxFFM}}\left(3.43 \pm 0.27 \mathrm{~L} / \mathrm{min}^{2}\right)$ compared with the Moderate under-eating group $\left(3.75 \pm 0.28 \mathrm{~L} / \mathrm{min}^{2}, \quad P<0.05\right)$. The Moderate and Low under-eating groups did not differ in $\mathrm{AEE} / \mathrm{kg}$, $\mathrm{BMI}$, or $\mathrm{VO}_{2 \text { maxFFM }}$.

$\mathrm{VO}_{2 \operatorname{maxFFM}}$ was positively related to AEE and $\mathrm{AEE} / \mathrm{kg}(r=0.44, P<0.05$ and $r=0.41, P<0.05$, respectively), but it had no relationship with $\mathrm{EE}$ (Table 4). BMI was negatively related to $\mathrm{AEE} / \mathrm{kg}$ $(r=-0.60, P<0.01)$ but it also had no relationship with EE or AEE (Table 4). In addition, in spite of the fact that BM did not change $(-0.4 \pm 1.8 \mathrm{~kg}$, NS) during the 2-week training period, energy balance was related to AEE $/ \mathrm{kg}(r=0.58, P<0.01)$ (Table 4). Table 5 shows the multivariate regression equations for explaining variation in $\mathrm{AEE} / \mathrm{kg}$. The model included energy balance, $\mathrm{VO}_{2 \operatorname{maxFFM}}$, and BMI. Only BMI remained in the model by explaining $33 \%$ of the variation in $\mathrm{AEE} / \mathrm{kg}$, with a standard error of estimate (SEE) of $0.02 \mathrm{MJ} / \mathrm{day} / \mathrm{kg}$ or $25 \%$ of the mean AEE $/ \mathrm{kg}$.

Table 4. Pearson correlation coefficients between $\mathrm{BMI}, \mathrm{VO}_{2 \max }$, and energy balance and $E E, A E E, A E E / k g$, and BMR

\begin{tabular}{|c|c|c|c|c|}
\hline & $\begin{array}{l}\mathrm{BMI} \\
\left(\mathrm{kg} / \mathrm{m}^{2}\right)\end{array}$ & $\begin{array}{l}\mathrm{VO}_{2 \max } \\
(\mathrm{L} / \mathrm{min})\end{array}$ & $\begin{array}{l}\mathrm{VO}_{2 \max F F M} \\
(\mathrm{~L} / \mathrm{min})^{*}\end{array}$ & $\begin{array}{l}\text { Energy } \\
\text { balance } \\
\text { (MJ/day) }\end{array}$ \\
\hline $\begin{array}{l}\text { EE (MJ/day) } \\
\text { AEE (MJ/day) } \\
\text { AEE/kg (MJ/day/kg) } \\
\text { BMR }\end{array}$ & $\begin{aligned} & 0.30 \\
- & 0.70 \\
- & 0.60^{\star \star} \\
& 0.58^{\star \star}\end{aligned}$ & $\begin{array}{l}0.77^{\star \star \star} \\
0.44^{\star} \\
-0.16 \\
0.66^{\star \star \star}\end{array}$ & $\begin{array}{l}0.29 \\
0.44^{\star} \\
0.41^{\star} \\
-0.10\end{array}$ & $\begin{array}{l}0.29 \\
0.21 \\
0.58^{\star \star} \\
-0.27\end{array}$ \\
\hline
\end{tabular}

$P<0.05 .{ }^{* *} P<0.01 .{ }^{* * *} P<0.001$.

$\star V \mathrm{O}_{2 \max }$ adjusted by FFM using a regression-based approach (Toth et al., 1993).

$E E$, energy expenditure, AEE, activity energy expenditure; AEE/kg, activity energy expenditure related to body mass; BMR, basal metabolic rate; FFM, fat-free mass.

Table 5. Multivariate regression model for explaining the variation in AEE/kg (MJ/day/kg)

\begin{tabular}{llll}
\hline Prediction equation & Adjusted- $R^{2}$ & SEE & $P$ \\
\hline $\mathrm{AEE} / \mathrm{kg}=0.165-(\mathrm{BMI} \times 0.003)$ & 0.33 & 0.02 & 0.002 \\
\hline
\end{tabular}

$\mathrm{AEE} / \mathrm{kg}$, activity energy expenditure related to body mass. 


\section{Tanskanen et al.}

\section{Discussion}

To our knowledge, there are no previous reports showing a relationship between $\mathrm{VO}_{2 \max }$ and activity (AEE $/ \mathrm{kg}$ ) during the BT season. The hypothesis was that the less fit conscripts would experience more physiological stress during physical activity, and that aerobic fitness would not be related to AEE $/ \mathrm{kg}$. Our contrary findings might partly be explained by the more intense participation and engagement of fit conscripts in military training. Moreover, in field situations the fit soldiers were often called upon to perform more military tasks. In support of this theory, endurance-trained cyclists have been found to have a significantly greater energy cost of cycling at the same relative intensity than untrained, less fit controls. This was due to the lower required workload of the less fit subjects to increase their heart rate to $75 \%$ of maximum, and thus their EE was also low (Horton et al., 1994). In contrast, during highintensity activities, the low absolute work capacity of the least-fit subjects might limit their work ability.

The strength of the present study was the use of a regression-based approach to remove the confounding influences of BM or FFM, rather than a standard ratio approach to express $\mathrm{VO}_{2 \max }$ values relative to BM $(\mathrm{mL} / \mathrm{kg} / \mathrm{min})$. The ratio method could lead to a significant and positive intercept, resulting automatically in higher values for lighter subjects (Toth et al., 1993). In the present study, the intercept for the regression of $\mathrm{VO}_{2 \max }$ with $\mathrm{BM}$ was significantly different from $0(P<0.01)$, but with FFM it was not. The best predictor of $\mathrm{VO}_{2 \max }(\mathrm{L} / \mathrm{min})$ was FFM, with a variation of $75 \%(r=0.87, P<0.001)$ compared with $\mathrm{BM}$ with the respective variation of $35 \%$ $(r=0.60, P<0.01)$. We therefore adjusted $\mathrm{VO}_{2 \max }$ for FFM. Very few studies have used DLW to estimate the relationship between AEE or EE and $\mathrm{VO}_{2 \max }$ (Ambler et al., 1998; Brochu et al., 1999). Our results are well in line with the study of Brochu et al. (1999), where they found a significant relationship between $\mathrm{VO}_{2 \max }$ and AEE in older individuals. The total EE in this study was similar (15.5 MJ/day) to that measured on a hilly terrain with temperatures ranging from $-1.1{ }^{\circ} \mathrm{C}$ to $16.1^{\circ} \mathrm{C}(14.24 \mathrm{MJ} /$ day $)$ (DeLany et al., 1989) and to a group of soldiers working in the garrison (Mudambo et al., 1997). However, the present EE was lower than that measured in jungle warfare (Forbes-Ewan et al., 1989), in a winter military training course (Hoyt et al., 1991; Jones et al., 1993), and in a commando field exercise in a hot and dry climate (Mudambo et al., 1997). The mean $( \pm \mathrm{SD})$ total EE of all male military personnel $(N=424)$ is reportedly $19.3 \pm 2.7 \mathrm{MJ} /$ day across all activities, military occupational specialties, and environments (Tharion et al., 2005). Comparisons in EE between the present study and other studies should be made with caution. For example, there are possible differences in the body mass of the subjects and in the combat gear that was carried, both of which affect the total EE.

In the multivariate regression analysis, only BMI remained in the model, although the correlation and one-way analysis revealed that positive energy balance and good fitness level were also related to higher activity $(\mathrm{AEE} / \mathrm{kg})$. In other words, the slimmer the subject, the smaller the loss of BM. This also suggests that more active subjects exhibit greater levels of aerobic fitness. This was partly explained by the fact that under-eating (negative energy balance) was negatively related to BMI. Thus, especially the subjects with a higher BMI were more prone to lose body mass than their slimmer counterparts. Even though negative energy balance was not significant $(-5.6 \%)$ at the group level, the individual variation in energy balance ranged from $-66.3 \%$ to $41.7 \%$. Based on Fig. 1, one-third of the subjects had a negative energy balance. However, in the present subjects, of whom one-third $(n=8)$ had a BMI over 25 , the acceptable tolerance limit for serious undereating classification is critical. The positive relationships observed between TrueEI and EE (Fig. 1), and between energy balance and $\mathrm{AEE} / \mathrm{kg}$ are well in line with other studies, where a low EI in males was found to be related to low EE (DeLany et al., 1989; Thompson et al., 1995), as well as to spontaneous physical activity (Thompson et al., 1995) when compared with an adequate EI group. Moreover, it has been shown that EE and AEE increase simultaneously with an increase in EI, which might be partly a reflection of EI to BMR (Klein \& Goran, 1993). However, Castellani et al. (2006) presented a contrary conclusion. They found that during a short period $(54 \mathrm{~h})$ of physical loading, recruits were able to maintain high EE and PAL despite sustaining substantial energy deficits.

The PAL value of 2.0 obtained during the present wintertime BT is comparable with values from people performing very strenuous work or daily competitive athletic training (Nordic Nutrition Recommendations, 2004). In addition, some subjects also ate less than required. If these stressors, together with other stressors, affect soldiers for a longer period, overtraining symptoms may occur (Meeusen et al., 2006). If the BMI is used as an index of body size, it was not associated with AEE, but was negatively related to AEE $/ \mathrm{kg}$ and positively to BMR (Table 4). Our findings further showed that BMR did not have any relationship with $\mathrm{VO}_{2 \max }$, but it was negatively related to $\mathrm{AEE} / \mathrm{kg}$. Among children it has been observed that AEE and EE tend to increase more with increasing body size than BMR (Ekelund et al., 2002). However, this was not seen in the present study, in which most military tasks were performed 
at low-to-moderate intensity levels. This meant that the least-fit subjects were able to perform those tasks well.

An additional purpose of the present study was to investigate the accuracy of a pre-filled food diary. Great care was taken to evaluate EI as correctly as possible without food weighing. In spite of the careful guidance and control, mis-recording was as high as $-20 \%$ and EI was only $74 \%$ of EE. It has been found that subjects who accurately reported their food intake at the first attempt were also able to do so at the second attempt (Goris et al., 2001). On the other hand, it is known that accuracy will decrease if the minimum recording time of 7 days is extended. This happens due to a decline in motivation in keeping the food diary (Goris et al., 2001). The calculation of under-eating, mis-recording, and an estimate of true EI were all based on changes in body $\mathrm{ES}$, in which the energy content of $30 \mathrm{MJ}$ corresponds to $1 \mathrm{~kg}$ of body mass. However, the mass ratio of $30 \mathrm{MJ} / 1 \mathrm{~kg}$ for storage or mobilization of energy between FM and FFM might differ individually, affecting the present results. We could have measured changes in body ES based on changes in FM and FFM, but 2 weeks may be too short a period to measure these parameters with sufficient accuracy. A more accurate method to estimate mis-recording and to calculate true EI involves a measure of water balance (Goris \& Westerterp, 1999), but this method still requires the recoding of food and fluid intake, which are both prone to mis-recording (Goris \& Westerterp, 1999; Goris et al., 2001; Westerterp \& Goris, 2002; Tharion et al., 2005).

\section{Perspectives}

The fitness level of Finnish young men has decreased with a concurrent increase in body mass (Santtila et al., 2006). Consequently, some conscripts entering compulsory military service have a low fitness level. However, the same program has to be performed by all conscripts in the military environment. The goal of physical training during the basic training season (BT) is to increase soldiers' aerobic fitness and muscle strength to prepare them for demanding military tasks. This leads to the question of whether fitness or body size affects the ability to train. In this study, the training load was assessed by relating activity $\mathrm{EE}$ to body mass (AEE $/ \mathrm{kg}$ ). The subjects with a low $\mathrm{VO}_{2 \max }$, a high $\mathrm{BMI}$, and a negative energy balance were vulnerable to low $\mathrm{AEE} / \mathrm{kg}$, but out of these three factors only BMI remained in the multivariate regression model. This indicates that overweight may limit the most the high-intensity physical training. In order to enhance physical fitness in a group of conscripts who exhibit variable fitness levels, these results suggest that conscripts could be divided into training groups simply based on BMI, rather than aerobic fitness level or a combination of these parameters.

Another issue is the importance of energy balance in sustaining a high training load. The results confirm that during BT, physical performance is affected by aerobic fitness and BMI as well as by energy balance. Initially, BMI has to be taken into consideration. Thereafter, energy balance should be optimized to facilitate physical performance, and to allow a high training load to be sustained during the BT season. This situation is comparable with that of athletes: without adequate EI, high-level training is not possible. Thus, because energy balance influenced $\mathrm{AEE} / \mathrm{kg}$, conscripts should be advised about adequate EI, especially during the most strenuous training period.

Key words: AEE, PAL, energy intake, under-reporting, under-eating, military training.

\section{Acknowledgements}

This study was funded by grants from the Finnish Ministry of Education, Finnish Cultural Foundation, Polar Electro Oy, and the Scientific Advisory Board for Defence.

\section{References}

American College of Sports Medicine (ACSM). Guidelines for exercise testing and prescription, 6th edn. Baltimore: Lippincott Williams \& Wilkins, 2001: 5-6, 57, 68, 117, 303.

Ainsworth BE, Haskell WL, Leon AS, Jacobs DR Jr., Montoye HJ, Sallis JF, Paffenbarger RS Jr. Compendium of physical activities: classification of energy costs of human physical activities. Med Sci Sports Exerc 1993: 25: 71-80.
Ambler C, Eliakim A, Brasel JA, Lee WN, Burke G, Cooper DM. Fitness and the effect of exercise training on the dietary intake of healthy adolescents. Int J Obes Relat Metab Disord 1998: 22: 354-362.

Black AE, Prentice AM, Coward WA. Use of food quotients to predict respiratory quotients for the doublylabelled water method of measuring energy expenditure. Hum Nutr Clin Nutr 1986: 40: 381-391.
Brochu M, Starling RD, Ades PA, Poehlman ET. Are aerobically fit older individuals more physically active in their free-living time? A doubly labeled water approach. J Clin Endocrinol Metab 1999: 84: 3872-3876.

Castellani JW, Delany JP, O'Brien C, Hoyt RW, Santee WR, Young AJ. Energy expenditure in men and women during $54 \mathrm{~h}$ of exercise and caloric deprivation. Med Sci Sports Exerc 2006: 38: 894-900. 


\section{Tanskanen et al.}

DeLany JP, Schoeller DA, Hoyt RW, Askew EW, Sharp MA. Field use of D2 180 to measure energy expenditure of soldiers at different energy intakes. J Appl Physiol 1989: 67: 1922-1929.

Deurenberg P, Weststrate JA, Seidell JC. Body mass index as a measure of body fatness: age- and sex-specific prediction formulas. Br J Nutr 1991: 65: 105-114.

Ekelund U, Aman J, Yngve A, Renman C, Westerterp K, Sjostrom M. Physical activity but not energy expenditure is reduced in obese adolescents: a casecontrol study. Am J Clin Nutr 2002: 76: 935-941.

Ekelund U, Yngve A, Brage S, Westerterp K, Sjostrom M. Body movement and physical activity energy expenditure in children and adolescents: how to adjust for differences in body size and age. Am $\mathbf{J}$ Clin Nutr 2004: 79: 851-856.

Forbes-Ewan CH, Morrissey BL, Gregg GC, Waters DR. Use of doubly labeled water technique in soldiers training for jungle warfare. J Appl Physiol 1989: 67: 14-18.

Goris AH, Meijer EP, Westerterp KR. Repeated measurement of habitual food intake increases under-reporting and induces selective under-reporting. Br J Nutr 2001: 85: 629-634.

Goris AH, Westerterp KR.

Underreporting of habitual food intake is explained by undereating in highly motivated lean women. J Nutr 1999: 129: 878-882.

Horton TJ, Drougas HJ, Sharp TA, Martinez LR, Reed GW, Hill JO. Energy balance in endurance-trained female cyclists and untrained controls. J Appl Physiol 1994: 76: 1936-1945.

Hoyt RW, Jones TE, Stein TP, McAninch GW, Lieberman HR, Askew EW, Cymerman A. Doubly labeled water measurement of human energy expenditure during strenuous exercise. J Appl Physiol 1991: 71: 16-22.

Jones BH, Knapik JJ. Physical training and exercise-related injuries. Surveillance, research and injury prevention in military populations. Sports Med 1999: 27: 111-125.

Jones PJ, Jacobs I, Morris A, Ducharme MB. Adequacy of food rations in soldiers during an arctic exercise measured by doubly labeled water. J Appl Physiol 1993: 75: 1790-1797.

Klein S, Goran M. Energy metabolism in response to overfeeding in young adult men. Metabolism 1993: 42: 1201-1205.

Knapik JJ, Sharp MA, Canham-Chervak M, Hauret K, Patton JF, Jones BH. Risk factors for training-related injuries among men and women in basic combat training. Med Sci Sports Exerc 2001: 33: 946-954.

Meeusen R, Duclos M, Gleeson M, Rietjens G, Steinacker J, Urhausen A. Prevention, diagnosis and treatment of the overtraining syndrome. Eur J Sport Sci 2006: 6: 1-14.

Mudambo KS, Scrimgeour CM, Rennie MJ. Adequacy of food rations in soldiers during exercise in hot, daytime conditions assessed by doubly labelled water and energy balance methods. Eur J Appl Physiol Occup Physiol 1997: 76: 346-351.

Nordic Nutrition Recommendations. Integrating nutrition and physical activity, 4th edn. Copenhagen: Nordic Council of Ministers, 2004: 121-125.

Pace N, Rathburn EN. Studies on body composition III: the body water and chemically combined nitrogen content in relation to fat content. J Biol Chem 1945: 158: 685-691.

Poehlman ET. A review: exercise and its influence on resting energy metabolism in man. Med Sci Sports Exerc 1989: 21: 515-525.

Popper R, Smits G, Meiselman HL, Hirsch E. Eating in combat: a survey of U.S. Marines. Mil Med 1989: 154: 619-623.

Santtila M, Kyrolainen H, Vasankari T, Tiainen S, Palvalin K, Hakkinen A, Hakkinen K. Physical fitness profiles in young Finnish men during the years 1975-2004. Med Sci Sports Exerc 2006: 38: 1990-1994.
Schoeller DA, Ravussin E, Schutz Y, Acheson KJ, Baertschi P, Jequier E. Energy expenditure by doubly labeled water: validation in humans and proposed calculation. Am J Physiol 1986: 250: R823-R830.

Schoeller DA, van Santen E, Peterson DW, Dietz W, Jaspan J, Klein PD. Total body water measurement in humans with $18 \mathrm{O}$ and $2 \mathrm{H}$ labeled water. Am J Clin Nutr 1980: 33: 2686-2693.

Tharion WJ, Lieberman HR, Montain SJ, Young AJ, Baker-Fulco CJ, DeLany JD, Hoyt RW. Energy requirements of military personnel. Appetite 2005: 44: 47-65.

Thompson JL, Manore MM, Skinner JS, Ravussin E, Spraul M. Daily energy expenditure in male endurance athletes with differing energy intakes. Med Sci Sports Exerc 1995: 27: 347-354.

Toth MJ, Goran MI, Ades PA, Howard DB, Poehlman ET. Examination of data normalization procedures for expressing peak $\mathrm{VO}_{2}$ data. $\mathrm{J}$ Appl Physiol 1993: 75: 2288-2292.

Training Division of the Defence Staff. The standard direction of the consripts physical training during the basic training season [in Finnish], 2003.

Weir JB. New methods for calculating metabolic rate with special reference to protein metabolism. J Physiol 1949: 109: 1-9.

Westerterp KR, Donkers JH, Fredrix EW, Boekhoudt P. Energy intake, physical activity and body weight: a simulation model. Br J Nutr 1995a: 73: 337-347.

Westerterp KR, Goris AH. Validity of the assessment of dietary intake: problems of misreporting. Curr Opin Clin Nutr Metab Care 2002: 5: 489-493.

Westerterp KR, Wouters L, van Marken Lichtenbelt WD. The Maastricht protocol for the measurement of body composition and energy expenditure with labeled water. Obes Res 1995b: 3(Suppl. 1): 49-57. 